\title{
PENGARUH REPUTASI UNIVERSITAS TERHADAP KEPUTUSAN MAHASISWA MEMILIH STUDI DI UNIVERSITAS ISLAM SUMATERA UTARA
}

\author{
Dedy Ansari Harahap ${ }^{* 1}$, Ratih Hurriyati ${ }^{2}$, Vanessa Gaffar ${ }^{3}$, Lili Adi Wibowo ${ }^{4} \&$ Dita Amanah $^{5}$ \\ *Email : dedyansariharahap@student.upi.edu \\ Universitas Pendidikan Indonesia ${ }^{1,2,3,4,5}$ \\ Universitas Islam Sumatera Utara ${ }^{1}$ \\ Universitas Negeri Medan ${ }^{5}$
}

\begin{abstract}
ABSTRAK
Penelitian ini bertujuan untuk menganalisis pengaruh reputasi universitas terhadap keputusan mahasiswa memilih studi di fakultas ekonomi Universitas Islam Sumatera Utara (UISU) Medan. Penelitian ini menggunakan pendekatan kuantitatif dengan tipe penelitian eksplanatori. Sampel penelitian berjumlah 177 responden dan diolah secara statistik dengan metode regresi linier sederhana. Hasil penelitian menunjukkan variabel reputasi universitas positif berpengaruh signifikan terhadap keputusan mahasiswa memilih studi. Temuan tersebut menunjukkan bahwa reputasi, integritas dan kredibilitas perguruan tinggi yang baik akan mendorong minat calon mahasiswa untuk memilih studi di suatu universitas seperti halnya di fakultas ekonomi UISU.
\end{abstract}

Kata kunci: Reputasi Universitas, Keputusan Mahasiswa Memilih, Fakultas Ekonomi dan UISU

\begin{abstract}
This study aims to analyze the influence of the university's reputation on the decision of students to choose a study at the faculty of economics of the Universitas Islam Sumatera Utara (UISU) Medan. This research uses quantitative approach with explanatory research type. The sample of the study amounted to 177 respondents and processed statistically with simple linear regression method. The results showed that the positive university reputation variable significantly influenced the decision of the students to choose the study. The findings indicate that the reputation, integrity and credibility of a good college will encourage the interest of prospective students to choose a study at a university as well as in the UISU economics faculty.
\end{abstract}

keyword: University Reputation, Student Decision to Choose, Faculty of Economics and UISU

\section{PENDAHULUAN}

Perguruan tinggi pada saat ini sebagai dunia usaha baru yang cukup potensial, bahkan kini reputasi sebuah universitas menjadi sangat penting dan menjadi modal utama bagi para pengembang usaha di bidang pendidikan. Reputasi yang bagus mencerminkan kualitas universitas. Tetapi hal ini bukanlah perkara mudah bagi setiap perguruan tinggi mengembangkan institusi perguruan tinggi nya di Indonesia, mengingat semakin ketatnya persaingan dengan perguruan tinggi lain.

Keputusan mahasiswa untuk melanjutkan studi pada tempat studi yang diinginkan adalah suatu keputusan dimana mahasiswa melakukan pertimbanganpertimbangan yang disesuaikan dengan keadaan atau kondisi yang ada. Jika keadaan atau kondisi yang terlihat tidak sesuai dengan apa yang diharapkannya, maka akan terjadi keraguan yang dapat berakibat pada keputusan untuk tidak memilih, dalam hal ini keputusan untuk tidak melanjutkan studi di tempat yang diharapkan. Pada kenyataannya pembuatan pilihan memiliki banyak dimensi dan dampak. Memilih merupakan bagian dari suatu upaya pemecahan sekaligus sebagai bagian dari proses pengambilan keputusan.

Menurut Alessandri, Yang, \& Kinsey (2006) dan studi Finch, Hamilton, Baldwin, \& Zehner (2013) menemukan bahwa reputasi universitas sangat penting bagi lulusan baru untuk mencari lowongan pekerjaan. Ini disebabkan setiap universitas menciptakan citra dan reputasi positif dalam menghadapi persaingan dengan universitas lainnya (Alessandri et al., 2006). Universitas harus lebih kompetitif di pasar pendidikan tinggi dalam menarik siswa terbaik dan memberikan peluang meraih kesempatan kerja terbaik untuk 
siswa yang diterima (Alessandri et al., 2006). Setiap universitas harus mampu menciptakan keunggulan bersaing sehingga dapat menarik siswa terbaik dan bekerja diperusahaan terbaik (Finch et al., 2013).

Lulusan universitas yang mempunyai reputasi universitas yang baik akan berdampak pada lulusan untuk bekerja di perusahaan sehingga berpengangaruh terhadap kinerja karyawan di setiap perusahaan. Setiap mahasiswa akan merasa bahwa studi di universitas akan menunjukkan tingkat keberhasilan mendapatkan pekerjaan yang diinginkan. Sehingga menimbulkan suatu kesan bagi perusahaan sebagai calon tenaga kerja yang diinginkan perusahaan di pasar kerja, membuat rasa bangga dan kelayakan lulusan di pasar kerja (Sultan \& Wong, 2012).

Universitas Islam Sumatera Utara disingkat UISU didirikan pada tanggal 7 Januari 1951, dengan perjuangan dan tekad yang kuat dari seluruh sivitas akademika UISU dan dukungan dari pemerintah, ulama dan masyarakat, saat ini UISU mengelola 9 Fakultas dan 26 Program Studi S-1, 3 Program Studi S-2, dan 1 Program Studi S-3 Ilmu Ekonomi dan Kebijakan kerjasama UISU dengan UII Jogjakarta. Fakultas dan Program Studi yang dibina antara lain Hukum, Agama Islam, Ekonomi, Sastra Inggris, Keguruan dan Ilmu Pendidikan, Ilmu Sosial dan Ilmu Politik, Pertanian, Kedokteran, Teknik dan Pascasarjana. Fakultas Ekonomi UISU didirikan oleh Yayasan Universitas Islam Sumatera Utara pada tanggal 16 februari 1957 yang merupakan Fakultas Ekonomi Swasta tertua di Sumatera (www.uisu.ac.id, n.d.).

\section{LANDASAN TEORI DAN}

\section{PENGEMBANGAN HIPOTESIS}

Keputusan Mahasiswa Memilih Studi Pengertian Keputusan Mahasiswa Memilih Studi

Pengambilan keputusan adalah suatu kegiatan individu yang secara langsung terlibat dalam mendapatkan dan mempergunakan barang yang ditawarkan. Keputusan konsumen merupakan salah satu bagian yang terdapat di dalam perilaku konsumen (Kotler, 2005). Menurut (Swastha \& Handoko, 2008) mengemukakan bahwa perilaku konsumen merupakan kegiatan-kegiatan individu secara langsung terlibat mendapatkan dan mempergunakan barang dan jasa termasuk dalam proses pengambilan keputusan.

Keputusan pembelian yang diasumsikan sebagai keputusan mahasiswa adalah salah satu faktor penting bagi setiap perguruan tinggi dalam menarik minat mahasiswa. Keputusan yang dipilih mahasiswa melanjutkan studi ke perguruan tinggi adalah kunci bagi kelangsungan siklus perguruan tinggi, karena mahasiswa merupakan aset bagi setiap perguruan tinggi. Keputusan yang diambil prinsipnya merupakan keputusan konsumen dalam memilih perguruan tinggi sebagai tempat untuk menuntut ilmu yang secara garis besar dijelaskan dalam perilaku konsumen.

Menurut Schiffman \& Kanuk (2007) keputusan pembelian adalah pemilihan dari dua atau lebih alternatif pilihan keputusan pembelian, artinya bahwa seseorang dapat membuat keputusan dari beberapa alternatif pilihan dan keputusan yang diambil mengarah pada bagaimana proses dalam pengambilan keputusan. Assauri (2010) menyatakan bahwa keputusan pembelian merupakan suatu proses pengambilan keputusan yang mencakup apa yang akan dibeli atau apa yang tidak dibeli.

Menurut Kotler (2005) menyatakan keputusan pembelian adalah suatu proses penyelesaian masalah yang terdiri dari menganalisa kebutuhan dan keinginan, pencarian informasi, penilaian sumber-sumber seleksi terhadap alternatif pembelian, keputusan pembelian, dan perilaku setelah pembelian. Perilaku konsumen akan menentukan proses pengambilan keputusan dalam pembelian. Sebelum memutuskan pembelian barang atau jasa, konsumen akan melalui beberapa tahapan. Proses pengambilan keputusan konsumen menurut Kotler, (2005) yaitu : 1). Pengenalan masalah (problem recognition), 2). Pencarian informasi 
(information search), 3). Evaluasi alternatif (validation of alternativ), 4). Keputusan Pembelian (purchase decision) dan 5). Perilaku pasca pembelian (Post Purchase behavior).

Sebagai seorang pemasar harus jeli melihat dan memperhitungankan pengaruh keputusan pembelian konsumen dalam membuat keputusan pembeliannya. Penelitian yang dilakukan Harahap (2015) menyatakan lokasi, harga dan kelengkapan produk secara simultan berpengaruh signifikan terhadap keputusan pembelian konsumen. Dapat disimpulkan bagi setiap perusahaan atau pedagang agar memperhatikan tempat usaha yang strategis, harga yang kompetitif dan kelengkapan produk yang bervariasi cukup tersedia untuk memenuhi kebutuhan konsumen yang membeli.

Dari pengertian keputusan pembelian diatas yang diasumsikan sebagai keputusan mahasiswa memilih studi. Dapat dsimpulkan keputusan memilih merupakan sikap calon mahasiswa terhadap suatu universitas untuk menentukan pilihan seseorang terhadap universitas yang dituju. Perilaku mahasiswa memilih studi menentukan suatu universitas yang dipilih untuk mencapai keinginan dan kebutuhan mahasiswa menuntut ilmu yang meliputi ; pengenalan berbagai universitas, pencarian informasi universitas, evaluasi terhadap alternatif memilih universitas, keputusan memilih universitas, dan perilaku setelah memilih universitas.

\section{Indikator Keputusan Mahasiswa Memilih Studi}

Menurut Kotler (2002) Indikator dari keputusan pembelian : kebutuhan yang dirasakan, kegiatan sebelum membeli, perilaku waktu memakai dan perilaku pasca pembelian. Pada penelitian ini keputusan pembelian yang dipersepsikan sebagai keputusan mahasiswa memilih studi di universitas diukur dengan menggunakan lima indikator pengukuran sebagai berikut, yakni : 1). Pengenalan universitas, 2). Pencarian informasi universitas, 3). Evaluasi terhadap alternatif memilih universitas, 4). Keputusan memilih universitas dan 5). Perilaku setelah memilih universitas.

\section{Reputasi Universitas \\ Pengertian Reputasi Universitas}

Reputasi merupakan suatu penilaian tentang keterkaitan sikap, emosi, keuangan, sosial dan budaya suatu organisasi dengan berbagai orang secara umum (Heath \& Vasquez, 2001). Menurut Fombrun \& Shanley (1990) Reputasi adalah bentuk keseluruhan yang menggambarkan penilaian dan sikap dari berbagai individual yang berkepentingan terhadap keadaan sebuah perusahaan.

Menurut Vercic \& Vercic (2007) dan Melewar, Karaosmanoglu, \& Peterson (2005) reputasi perusahaan dipahami sebagai fungsi citra dan identitas yang dibentuk dalam perusahaan berdasarkan budaya organisasinya seperti sejarah perusahaan, kegiatannya, nilai dan perilaku. Citra dibentuk dalam setiap pemikiran stakeholder eksternal tentang kesan sementara orang terhadap organisasi yang dibentuk dari pengalaman dan bagaimana menerima identitas organisasi pada situasi tertentu (Balmer \& Greyser, 2002; Melewar et al., 2005; Hatch \& Schultz, 1997).

Menurut Post \& Griffin (1997) menyatakan bahwa reputasi adalah kombinasi antara opini, persepsi, dan perilaku para pemangku kepentingan dari suatu organisasi. Sejalan dengan pendapat Eberl \& Schwaiger (2005) reputasi adalah semacam konstruksi perilaku secara umum yang berfungsi dalam benak publik. Reputasi juga diinterpretasikan sebagai sekumpulan fakta yang dialami dan dirasa dari produk melalui proses sosial dan bukan merupakan kesan dalam pikiran orang secara pribadi (Helm, 2007).

Reputasi bagi sebuah organisasi merupakan asset vital yang tidak tampak, ketika dikelola dengan tepat, reputasi dapat meningkatkan kemampuan organisasi untuk menjual produk dan jasanya, menarik investor, mempekerjakan pekerja yang berbakat dan mengantisipasi pengaruh situasi 
politik sekitarnya. Reputasi yang baik akan mendatangkan banyak manfaat dan keuntungan sebaliknya reputasi yang buruk dapat menjatuhkan sebuah organisasi (Heath \& Vasquez, 2001). Ada empat hal yang mempengaruhi reputasi sebuah organisasi yaitu ; kredibilitas, kehandalan, tanggung jawab dan trustworthiness, Sehingga keempatnya berhubungan saling mempengaruhi dan secara bersama-sama akan membentuk reputasi organisasi (Fombrun \& Shanley, 1990).

Jung \& Seock (2016) menyatakan bahwa manajer pemasaran perlu mengelola reputasi negatif secara hati-hati karena reputasi negatif perusahaan akan memperburuk proses pemikiran konsumen, konsumen tidak dipengaruhi oleh jenis informasi negatif tertentu jadi perusahaan dapat mengurangi pengaruh negatif dari reputasi negatif dengan jenis reputasi positif lainnya. Jika pelanggan membentuk persepsi negatif terhadap perusahaan atau produknya maka penjualan dan keuntungan bisa menyebabkan terjadinya penurunan (Gray \& Balmer, 1998).

Selama beberapa tahun terakhir diskusi tentang konstruk dan konten reputasi telah muncul di kalangan akademisi (Jarvinem \& Suomi, 2011). Berbagai studi telah mengakui pentingnya reputasi dalam konteks pendidikan tinggi (Vidaver-Cohen, 2007;Helgesen, 2008;Alessandri et al., 2006). Pembangunan reputasi dan branding telah menjadi elemen sentral dalam praktik baru manajemen universitas (H. Aula \& Tienari, 2011). Pemeliharaan kualitas dan reputasi institusi telah memperoleh perhatian serius peneliti (Hilgers, Flachsbart, \& Elrod, 2012).

Mazzarol \& Soutar (2012) menyebut "strong reputation" sebagai satu kompetensi kunci bagi institusi pendidikan untuk sukses bersaing di pasar global. Banyak universitas terlibat dalam strategi rekonstruksi citra untuk mereposisi diri mereka sendiri di pasar pendidikan dan memperbaiki reputasi mereka (Brown, Dacin, Pratt, \& Whetten, 2006).

Secara spesifik, norma institusional, mekanisme insentif, reputasi universitas, intermediary agents, dan karakteristik pengajar telah dijelaskan memainkan suatu peran fundamental untuk membuat beberapa universitas lebih bersifat kewirausahaan dibanding yang lain ;(Etzkowitz, Webster, Gebhardt, Regina, \& Terra, 2000;Thursby, Thursby, \& Gupta-Mukherjee, 2005; Boardman \& Ponomariov, 2009; Giuliani \& SPRU, 2010; Prodan \& Drnovsek, 2010).

Meskipun reputasi berperan penting, kenyataannya studi Gaultier-Gaillard \& Louisot (2006) mengungkapkan bahwa hanya enam belas persen perusahaan yang telah memformalkan proses kuantifikasi untuk mengukur dan memonitor reputasi. Lainnya menggunakan informasi yang bersifat informal dan peringkat yang dipublikasikan. Di dunia akademik, peringkat global dan akreditasi telah memperoleh posisi penting dan reputasi telah menjadi perhatian utama bagi pengambil keputusan (Wedlin, 2006; Ressler \& Abratt, 2009). Universitas didorong untuk bersaing secara global untuk menarik perhatian financiers, akademik, siswa, dan perusahaan (H. Aula \& Tienari, 2011).

Pentingnya peringkat telah tumbuh secara signifikan karena permintaan untuk evaluasi institusi akademik telah meningkat dan modus tata kelola mereka telah menjadi lebih berbasis pasar (Engwall, 2007). Daftar peringkat global telah menjadi sebuah penilaian kualitas yang penting bagi universitas (Wedlin, 2006). Namun demikian, pemeringkatan juga telah dikritisi karena dinilai menggunakan kriteria yang menyenangkan universitas yang telah ada dalam daftar (Policano, 2007; Morgeson \& Nahrgang, 2008). Akreditasi menawarkan sudut pandang lain untuk mempertimbangkan pembangunan reputasi di universitas. Sekolah bisnis khususnya menjadi aktif dalam audit eksternal oleh badan akreditasi internasional yang dikenal baik, dengan tujuan memperoleh dan mempertahankan stempel keunggulan internasional (H. Aula \& Tienari, 2011).

Meningkatnya perhatian atas akuntabilitas eksternal telah menggerakkan riset tentang pembangunan reputasi 
(reputation-building). Studi menggambarkan dinamika pembangunan reputasi dalam sebuah universitas (H. Aula \& Tienari, 2011). Persaingan di antara universitas tidak hanya terjadi secara lokal dan nasional, tetapi juga secara global. Dalam ekonomi global, membangun reputasi dan branding adalah sangat penting (Kornberger, 2010). Oleh karena itu, ke depan studi yang fokus pada konteks pendidikan tinggi akan sangat berguna (Jarvinem \& Suomi, 2011).

Dari beberapa definisi diatas dapat disimpulkan bahwa reputasi adalah kombinasi antara opini, persepsi dan perilaku setiap individu atau organisasi dalam memberikan penilaian sepanjang waktu tentang performa organisasi atau perusahaan berdasarkan pada keterkaitan emosi, finansial, sosial dan kultural antara organisasi dengan yang berkepentingan. Dari semua penjelasan dalam latar belakang penelitian ini maka dapat disimpulkan reputasi universitas menjadi hal yang sangat penting untuk dipertimbangkan oleh calon mahasiswa dalam menentukan sikap tepat untuk melanjutkan studi di perguruan tinggi sesuai kebutuhan dan keinginan.

Reputasi universitas dapat diukur dari kepopuleran nama universitas (brand identity), jumlah pendaftar secara keseluruhan dan rasio antara jumlah yang diterima dengan jumlah pendaftar (Indrajit \& Djokopranoto, 2006). Reputasi universitas juga digambarkan sebagai representasi keseluruhan yang dipegang oleh berbagai universitas selama ini (Alessandri et al., 2006). Dengan menerapkan prinsip umum suatu reputasi yang dikemukakan oleh (Bromley, 2006;Caruana, 2002; Gotsi \& Wilson, 2001;Fombrun \& Shanley, 1990;Grunig, Sriramesh, Huang, \& Lyra, 1995;Alessandri et al., 2006) merumuskan bahwa reputasi sebuah universitas dapat dibentuk berdasarkan pengalaman lulusan perguruan tinggi dalam berinteraksi langsung atau tidak langsung melalui informasi dan komunikasi dari universitas.

\section{Indikator Reputasi Universitas}

Sontaite, M. dan Bakanauskas (2011) ada sepuluh indikator dalam pengukuran reputasi perusahaan di institusi pendidikan tinggi yaitu: daya tarik emosional, perilaku, studi, citizenship dan tanggung jawab sosial, kepemimpinan, kinerja, tempat kerja, persaingan, karir, dan inovasi. Faktor yang dinilai paling penting bagi pelanggan institusi atau lembaga pendidikan tinggi yaitu : Inovasi, Perilaku, Kinerja dan Studi. Indikator yang paling tidak penting dari pengukuran reputasi korporasi bagi pelanggan lembaga pendidikan tinggi yaitu: pemimpin yang menarik, tanggung jawab lingkungan, value for money dan kekaguman.

\section{Hipotesis}

Hipotesis dalam penelitian ini adalah:

$\mathrm{H}_{1}$ : Terdapat pengaruh reputasi universitas terhadap keputusan mahasiswa memilih studi di fakultas ekonomi UISU. 


\section{Penelitian yang Relevan}

Tabel 1. Penelitian Yang Relevan.

\begin{tabular}{|c|c|c|c|c|}
\hline Peneliti & Judul & Hasil & Implikasi & Jurnal \\
\hline $\begin{array}{l}\text { Petruzzellis \& } \\
\text { Romanazzi } \\
(2010)\end{array}$ & $\begin{array}{l}\text { Educational value : how } \\
\text { students choose } \\
\text { university }\end{array}$ & $\begin{array}{l}\text { Temuan menunjukkan bahwa } \\
\text { retensi dan minat siswa } \\
\text { memilih universitas adalah } \\
\text { meningkatkan tingkat kepuasan } \\
\text { siswa, melalui pelayanan dan } \\
\text { membantu siswa mencapai } \\
\text { tujuan serta pentingnya nilai } \\
\text { sosial atau nama baik } \\
\text { universitas. }\end{array}$ & $\begin{array}{l}\text { Penelitian selanjutnya harus } \\
\text { ditujukan untuk menentukan } \\
\text { nilai seumur hidup siswa } \\
\text { baik dari universitas maupun } \\
\text { sudut pandang siswa. Selain } \\
\text { itu, dapat menarik untuk } \\
\text { menyelidiki semacam } \\
\text { "kesetaraan siswa" sebagai } \\
\text { fungsi dari: kepuasan siswa } \\
\text { serta pengorbanan siswa. }\end{array}$ & $\begin{array}{l}\text { International } \\
\text { Journal of } \\
\text { Educational } \\
\text { Management } \\
\text { Vol. 24 No. 2, } \\
\text { pp. 139-158 } \\
\text { Emerald Group } \\
\text { Publishing } \\
\text { Limited }\end{array}$ \\
\hline $\begin{array}{l}\text { N. Harahap } \\
(2004)\end{array}$ & $\begin{array}{l}\text { Analisis Faktor-Faktor } \\
\text { yang Mempengaruhi } \\
\text { Keputusan Mahasiswa } \\
\text { dalam Menempuh } \\
\text { Pendidikan Politeknik } \\
\text { LP3I Medan }\end{array}$ & $\begin{array}{l}\text { Menunjukkan secara bersama- } \\
\text { sama variabel bebas proses, } \\
\text { biaya, latar belakang sosial } \\
\text { ekonomi, motivasi, fasilitas, } \\
\text { referensi, lokasi, promosi, } \\
\text { reputasi, dan alumni } \\
\text { mempunyai pengaruh yang } \\
\text { signifikan terhadap keputusan } \\
\text { mahasiswa menempuh } \\
\text { pendidikan pada Politeknik } \\
\text { LP3I Medan }\end{array}$ & $\begin{array}{l}\text { Dari beberapa faktor yang } \\
\text { diteliti maka universitas } \\
\text { harus memperhitungkan } \\
\text { faktor utama menarik minat } \\
\text { calon mahasiswa memilih } \\
\text { memasuki universitas seperti } \\
\text {; reputasi, promosi, biaya } \\
\text { dan faktor-faktor lain yang } \\
\text { mendukung melalui } \\
\text { penelitian selanjutnya. }\end{array}$ & $\begin{array}{l}\text { Tesis Program } \\
\text { Pasca Sarjana } \\
\text { Program Studi } \\
\text { Ilmu Manajemen } \\
\text { Universitas } \\
\text { Sumatera Utara, } \\
\text { Medan. (tidak } \\
\text { dipublikasikan). }\end{array}$ \\
\hline $\begin{array}{l}\text { Khoiriyah, } \\
\text { Susilawati, \& } \\
\text { Nilakusumawati } \\
\text { (2013) }\end{array}$ & $\begin{array}{l}\text { Faktor- Faktor yang } \\
\text { Mempengaruhi Minat } \\
\text { Mahasiwa Asal Luar } \\
\text { Bali Kuliah di FMIPA } \\
\text { Universitas Udayana } \\
\text { Bali }\end{array}$ & $\begin{array}{l}\text { Ada delapan faktor yang } \\
\text { memengaruhi minat mahasiswa } \\
\text { luar Bali kuliah di FMIPA } \\
\text { Universitas Udayana Bali yaitu } \\
\text { produk, referensi, reputasi, } \\
\text { biaya, latar belakang sosial } \\
\text { ekonomi, motivasi, lokasi dan } \\
\text { promosi. }\end{array}$ & $\begin{array}{l}\text { Dari hasil Penelitian reputasi } \\
\text { mempunyai peranan penting } \\
\text { bagi calon mahasiswa dalam } \\
\text { menentukan universitas } \\
\text { mana yang dipilih } \\
\text { disamping faktor-faktor lain } \\
\text { dapat dilakukan penelitian. }\end{array}$ & $\begin{array}{l}\text { e-Jurnal } \\
\text { Matematika } \\
\text { Vol.2, No.1, } \\
\text { Januari 2013, 24- } \\
32 .\end{array}$ \\
\hline $\begin{array}{l}\text { Andriani \& } \\
\text { Adam (2013) }\end{array}$ & $\begin{array}{l}\text { Pengaruh Biaya } \\
\text { Pendidikan, Latar } \\
\text { Belakang Sosial } \\
\text { Ekonomi, Motivasi dan } \\
\text { Reputasi Terhadap } \\
\text { Minat Mahasiswa dalam } \\
\text { Memilih Prodi S1 } \\
\text { Akuntansi Perguruan } \\
\text { Tinggi di Malang. }\end{array}$ & $\begin{array}{l}\text { Hasil penelitian ini } \\
\text { menunjukkan bahwa variabel } \\
\text { motivasi dan reputasi } \\
\text { berpengaruh positif terhadap } \\
\text { minat dalam memilih prodi S1 } \\
\text { Akuntansi. Sedangkan variabel } \\
\text { biaya pendidikan dan latar } \\
\text { belakang sosial ekonomi } \\
\text { berpengaruh negatif terhadap } \\
\text { minat mahasiswa dalam } \\
\text { memilih prodi S1 akuntansi. }\end{array}$ & $\begin{array}{l}\text { Penelitian selanjutnya } \\
\text { diharapkan menambahkan } \\
\text { variabel selain yang diteliti } \\
\text { agar dapat mengetahui faktor } \\
\text { paling berpengaruh yang } \\
\text { mempengaruhi minat } \\
\text { mahasiswa dalam memilih } \\
\text { prodi S1 Akuntansi. } \\
\text { Sehingga diharapkan } \\
\text { memperlebar daerah } \\
\text { populasinya tidak hanya di } \\
\text { enam perguruan tinggi saja, } \\
\text { sehingga dapat digeneralisasi } \\
\text { secara lebih luas. }\end{array}$ & $\begin{array}{l}\text { Jurnal Ilmiah } \\
\text { Mahasiswa FEB } \\
\text { Universitas } \\
\text { Brawijaya. } \\
\text { Malang, 1(2), 14- } \\
17 .\end{array}$ \\
\hline $\begin{array}{l}\text { Fernandez } \\
\text { (2010) }\end{array}$ & $\begin{array}{l}\text { An Exploratory Study of } \\
\text { Factors Influencing The } \\
\text { Decision of Students to } \\
\text { Study at Universiti Sains } \\
\text { Malaysia }\end{array}$ & $\begin{array}{l}\text { Hasil penelitian ini } \\
\text { menunjukkan alasan utama } \\
\text { mengapa siswa menempuh } \\
\text { pendidikan tinggi adalah } \\
\text { memperbaiki prospek pekerjaan } \\
\text { dan untuk mendapatkan } \\
\text { pengetahuan dan pengalaman } \\
\text { dari sebuah universitas yang } \\
\text { bereputasi. }\end{array}$ & $\begin{array}{l}\text { Pilihan siswa untuk institusi } \\
\text { publik terutama dipengaruhi } \\
\text { oleh pertimbangan kualitas } \\
\text { pendidikan dan faktor-faktor } \\
\text { uang. Akhirnya, keputusan } \\
\text { untuk belajar di USM } \\
\text { dikaitkan dengan hubungan } \\
\text { bisnis USM yang kuat, } \\
\text { reputasi yang baik, memadai. }\end{array}$ & $\begin{array}{l}\text { Kajian Malaysia, } \\
\text { Vol. 28, No. 2, pp. } \\
\text { 107-136. }\end{array}$ \\
\hline
\end{tabular}




\section{METODE PENELITIAN}

Penelitian ini dilakukan di Universitas Islam Sumatera Utara khususnya fakultas ekonomi yang beralamat di Jalan Sisingamangaraja Teladan Barat Medan. Populasi dalam penelitian ini adalah seluruh mahasiswa semester II T.A. 2015/2016 Fakultas Ekonomi UISU yaitu sebesar 317 orang. Teknik sampel yang digunakan yaitu non probability sampling, jumlah sampel atau responden yang harus diteliti adalah 177 responden. Data dikumpulkan melalui teknik kuesioner dan teknik analisis data menggunakan pendekatan kuantitatif dengan tipe penelitian explanatory research (penelitian penjelasan) model analisis regresi sederhana. Perhitungan analisis menggunakan program SPSS (Statistical Packages for the Social Science) versi 22.00 Windows.

\section{HASIL ANALISIS DAN PEMBAHASAN \\ HASIL ANALISIS \\ Uji Validitas dan Reliabilitas}

Tabel 2. Hasil Uji Validitas dan Realibilitas

\begin{tabular}{|c|c|c|c|c|c|c|c|}
\hline Variabel & Pernyataan & $\mathbf{r}_{\text {hitung }}$ & $\mathbf{r}_{\text {tabel }}$ & Status & $\begin{array}{c}\text { Cronbach } \\
\text { Alpha }\end{array}$ & $\mathbf{r}_{\text {tabel }}$ & Status \\
\hline $\begin{array}{l}\text { Reputasi } \\
\text { Universitas } \\
\text { (X) }\end{array}$ & $\begin{array}{l}\text { X1 } \\
\text { X2 } \\
\text { X3 } \\
\text { X4 } \\
\text { X5 } \\
\text { X6 } \\
\text { X7 } \\
\text { X8 } \\
\text { X9 }\end{array}$ & $\begin{array}{l}.837 \\
.843 \\
.801 \\
.870 \\
.767 \\
.565 \\
.704 \\
.693 \\
.760\end{array}$ & $\begin{array}{l}.361 \\
.361 \\
.361 \\
.361 \\
.361 \\
.361 \\
.361 \\
361 \\
.361\end{array}$ & $\begin{array}{l}\text { Valid } \\
\text { Valid } \\
\text { Valid } \\
\text { Valid } \\
\text { Valid } \\
\text { Valid } \\
\text { Valid } \\
\text { Valid } \\
\text { Valid }\end{array}$ & .907 & .361 & Reliabel \\
\hline $\begin{array}{l}\text { Keputusan } \\
\text { Mahasiswa } \\
\text { Memilih (Y) }\end{array}$ & $\begin{array}{c}\text { Y1 } \\
\text { Y2 } \\
\text { Y3 } \\
\text { Y4 } \\
\text { Y5 } \\
\text { Y6 } \\
\text { Y7 } \\
\text { Y8 } \\
\text { Y9 } \\
\text { Y10 }\end{array}$ & $\begin{array}{l}.705 \\
.598 \\
.810 \\
.684 \\
.587 \\
.748 \\
.878 \\
.782 \\
.832 \\
.715\end{array}$ & $\begin{array}{l}.361 \\
.361 \\
.361 \\
.361 \\
.361 \\
.361 \\
.361 \\
.361 \\
.361 \\
.361\end{array}$ & $\begin{array}{l}\text { Valid } \\
\text { Valid } \\
\text { Valid } \\
\text { Valid } \\
\text { Valid } \\
\text { Valid } \\
\text { Valid } \\
\text { Valid } \\
\text { Valid } \\
\text { Valid }\end{array}$ & .901 & .361 & Reliabel \\
\hline
\end{tabular}

Sumber: Hasil Olah Data

Tabel 2 menunjukkan dari 9 (sembilan) butir pernyataan variabel reputasi universitash dan 10 (sepuluh) butir pernyataan variabel keputusan mahasiswa memilih dinyatakan valid dimana nilai $\mathrm{r}_{\text {hitung }}>\mathrm{r}_{\text {tabel }}$ pada taraf signifikan 0,05 dengan nilai $r$ tabel adalah
0,361. Hasil perhitungan reliabilitas dengan menggunakan uji alpha cronbach hasilnya pada reputasi universitasth sebesar 0,907 dan variabel keputusan mahasiswa memilih sebesar 0,901. Nilai ini lebih besar jika dibandingkan dengan nilai $r$ tabel pada taraf 
signifikan 0,05 yaitu sebesar 0,361. Jadi dapat disimpulkan instrumen yang digunakan dalam angket penelitian ini adalah reliabel ( $\mathrm{r}_{\text {hitung }}>\mathrm{r}$ tabel).

\section{Analisis Regresi Sederhana}

Model regresi sederhana dengan satu variabel terikat $(\mathrm{Y})$ yaitu keputusan mahasiswa memilih studi dan satu variabel bebas yaitu reputasi universitas $(\mathrm{X})$ adalah :

$$
\mathrm{Y}=\mathbf{0 , 5 3 9}+\mathbf{0 , 8 4 3}+\mathrm{e}
$$

Tabel 3. Regresi Linear Sederhana

\begin{tabular}{cc}
\hline Model & $\begin{array}{c}\text { Unstandarized } \\
\text { Coefficients }\end{array}$ \\
\cline { 2 - 2 } & $B$
\end{tabular}

(Constant) .539

Reputasi Universitas .843

Sumber: Hasil Olah Data

Dari Tabel 3 menunjukan persamaan regresi $\quad Y=\mathbf{0 , 5 3 9}+\mathbf{0 , 8 4 3 X}+\mathbf{X}$ menggambarkan bahwa variabel bebas (independen) reputasi universitas (X) dalam model regresi dapat dinyatakan jika variabel independen berubah sebesar 1 (satu) dan lainnya konstan, maka perubahan variabel terikat (dependen) keputusan mahasiswa memilih (Y) sebesar nilai koefisien $(b)$ dari nilai variabel independen tersebut. Konstanta ( $\alpha$ ) sebesar 0.539 memberikan pengertian bahwa jika reputasi universitas (X) tidak mengalami perubahan atau sama dengan nol (0) maka besarnya keputusan mahasiswa memilih (Y) sebesar 0.539 satuan.

Jika nilai $b$ yang merupakan koefisien regresi dari reputasi universitas $(\mathrm{X})$ sebesar 0.843 yang artinya mempunyai pengaruh positif terhadap variabel dependen (Y) bahwa jika variabel reputasi universitas (X) bertambah 1 satuan, maka keputusan mahasiswa memilih(Y) akan mengalami kenaikan sebesar 0.843 satuan dengan asumsi variabel lain tetap atau konstan.
Uji hipotesis $t$

Tabel 4. Uji t

\begin{tabular}{|c|c|c|}
\hline \multirow[b]{2}{*}{ Model } & \multicolumn{2}{|c|}{ Uji t } \\
\hline & t Hitung & t Tabel \\
\hline (Constant) & 2.602 & 1.654 \\
\hline Reputasi Universitas & 15.608 & 1.654 \\
\hline
\end{tabular}

Hasil analisis uji parsial (uji t) pada variabel reputasi universitas $(\mathrm{X})$ diperoleh angka $t_{\text {hitung }}$ sebesar 15,608 sedangkan angka $\mathrm{t}_{\text {tabel }}$ diperoleh sebesar $=1,654$, karena nilai $t_{\text {hitung }}>t_{\text {tabel }}$, maka $\mathrm{Ho}_{1}$ ditolak dan $\mathrm{Ha}_{1}$ diterima. Hal ini berarti hipotesis diterima yaitu reputasi universitas positif berpengaruh secara signifikan terhadap keputusan mahasiswa memilih studi.

Koefisien Determinasi

Tabel 5. Koefisien Determinasi $\left(\mathbf{R}^{2}\right)$

\begin{tabular}{cccc}
\hline Model & $\mathbf{R}$ & $\boldsymbol{R}$ & $\begin{array}{c}\text { Adjusted } \boldsymbol{R} \\
\text { Square }\end{array}$ \\
\hline 1 & $.763^{\mathrm{a}}$ & .582 & .580 \\
\hline Sumber: Hasil Olah Data
\end{tabular}

Tabel 5 menunjukkan bahwa nilai $\mathrm{R}$ yang dihasilkan adalah sebesar 0.763 artinya mempunyai hubungan kuat. Nilai $\mathrm{R}$ square $\left(\mathrm{R}^{2}\right)$ adalah 0,582 atau $58,20 \%$ artinya pengaruh variabel bebas reputasi universitas (X) terhadap variabel terikat keputusan mahasiswa memilih adalah sebesar 58,20\% dan sisanya sebesar $41,80 \%$ di pengaruhi variabel lain.

\section{PEMBAHASAN}

Hasil penelitian yang telah dilakukan pada variabel reputasi universitas positif berpengaruh secara signifikan terhadap keputusan mahasiswa memilih studi di fakultas ekonomi UISU Indonesia. Dapat dilihat dari nilai koefisien regresi reputasi universitas dengan uji parsial (uji t) dengan nilai $t_{\text {hitung }}>\mathrm{t}_{\text {tabel }}$ yaitu $15,608>1,654$ pada tingkat signifikansi $0,000<0,05$ yang berarti signifikan untuk menilai keputusan mahasiswa 
memilih studi karena lebih kecil dari 5\%, maka hipotesis diterima, artinya positif terdapat pengaruh secara signifikan antara reputasi universitas terhadap keputusan mahasiswa memilih studi di fakultas ekonomi UISU Indonesia.

Hasil ini didukung penelitian yang dilakukan oleh Ivy (2008) menyebutkan bahwa ketenaran (reputasi) merupakan salah satu faktor penentu siswa dalam memilih sekolah bisnis. Secara lengkap, faktor-faktor terpenting berdasarkan urutan adalah: program (pilihan jurusan), ketenaran/terkenal (reputasi), harga (biaya kuliah), prospektus (komunikasi melalui direct mail), people (interaksi dengan pengajar, karyawan, dan siswa lain), promosi (publisitas dan e-media), dan bonus (gabungan berbagai penawaran). N. Harahap, (2004) menemukan bahwa secara parsial reputasi mempunyai pengaruh terhadap keputusan mahasiswa dalam menempuh pendidikan. Andriani \& Adam (2013) reputasi berpengaruh positif terhadap minat mahasiswa dalam memilih prodi S1 Akuntansi serta penelitian Khoiriyah et al. (2013) yang menemukan bahwa faktor lokasi, biaya, produk, latar belakang sosial ekonomi, motivasi, fasilitas, referensi, promosi, dan reputasi mempunyai pengaruh terhadap minat mahasiswa luar Bali kuliah. Sojkin, Bartkowiak, \& Skuza (2012) dalam penelitiannya menemukan bahwa reputasi universitas yang dirasakan melalui kualitas studi yang tinggi sesuai dengan standar Eropa dan potensi pendapatan yang mungkin mereka dapatkan setelah lulus universitas melalui kemajuan profesional menentukan pilihan universitas bagi siswa di Polandia.

Hal ini didukung pernyataan Robbins (2007) bahwa reputasi menjadi hal penting karena berhubungan dengan nama baik yang tentu akan mempengaruhi pandangan atau persepsi seseorang. Jadi dapat disimpulkan bahwa reputasi universitas merupakan determinan yang sangat penting terhadap minat calon mahasiswa dalam memilih perguruan tinggi khususnya di fakultas ekonomi UISU Indonesia. Hasil penelitian diperoleh nilai $\mathrm{R}^{2}$ sebesar 0,582 yang berarti variabel independen (reputasi universitas) memberikan pengaruh terhadap variabel dependen (keputusan mahasiswa memilih studi) sebesar $58,20 \%$, sedangkan sisanya $41,80 \%$ dijelaskan oleh faktor lain diluar dari variabel penelitian ini.

\section{PENUTUP \\ Simpulan}

Berdasarkan hasil analisis regresi sederhana dengan perhitungan uji hipotesis secara parsial (Uji-t) pada variabel reputasi universitas positif berpengaruh signifikan terhadap keputusan mahasiswa memilih studi dengan nilai t-hitung > t-tabel, hal ini menyatakan bahwa $\mathrm{H}_{0}$ ditolak dan $\mathrm{Ha}$ diterima, sehingga dapat disimpulkan bahwa reputasi universitas positif berpengaruh signifikan terhadap keputusan mahasiswa memilih studi.

\section{Saran}

Universitas Islam Sumatera Utara sebagai pengelola perguruan tinggi swasta harus terus berupaya lebih profesional dalam memenuhi sarana dan prasarana yang dibutuhkan, peningkatan kualitas dan kualifikasi dosen yang dimiliki. Program studi yang dikelola lebih kreatif dan memprioritaskan program studi yang berbasis ketrampilan khusus sesuai yang dibutuhkan pasar kerja. Persaingan yang ketat di era MEA hampir di semua sektor mengalami termasuk perguruan tinggi maka perguruan tinggi dituntut selalu membangun reputasi yang baik secara internal maupun eksternal terkait dengan loyalitas mahasiswa yang sangat berpengaruh terhadap citra dan reputasi universitas.

\section{Rekomendasi Penelitian Selanjutnya}

Penelitian ini hanya memfokuskan pada variabel reputasi universitas sebagai faktor yang berpengaruh terhadap keputusan mahasiswa memilih studi sehingga hanya mampu menjelaskan sebesar $58,60 \%$. Peneliti selanjutnya diharapkan mampu menambah variabel-variabel lain seperti ; citra, promosi, pelayanan, keamanan dan kenyamanan yang dapat mempengaruhi keputusan mahasiswa memilih studi. Sehingga dapat memberikan 
kontribusi yang baik untuk penelitian selanjutnya tentang keputusan mahasiswa memilih studi di perguruan tinggi.

\section{DAFTAR PUSTAKA}

Alessandri, S. W., Yang, S.-U., \& Kinsey, D. F. (2006). An Integrative Approach to University Visual Identity and Reputation. Corporate Reputation Review, 9(4), 258-270. https://doi.org/10.1057/palgrave.crr.1550 033

Andriani, E., \& Adam, H. (2013). Pengaruh Biaya Pendidikan, Latar Belakang Sosial Ekonomi, Motivasi dan Reputasi Terhadap Minat Mahasiswa dalam Memilih Prodi S1 Akuntansi Perguruan Tinggi di Malang. Jurnal Ilmiah Mahasiswa FEB Universitas Brawijaya. Malang, 1(2), 14-17.

Assauri, S. (2010). Manajemen Pemasaran. Jakarta: Rajawali Pers.

Aula, H., \& Tienari, J. (2011). Becoming “ world-class "? Reputation-building in a university merger. Critical Perspectives on International Business, 7(1), 7-29. https://doi.org/10.1108/17422041111103 813

Balmer, J. M. T., \& Greyser, S. A. (2002). Managing the Multiple Identities of the Corporation. California Management Review, 44(3), 72-86.

Boardman, P. C., \& Ponomariov, B. L. (2009). University researchers working with private companies. Technovation, 29(February), 142-153. https://doi.org/10.1016/j.technovation.20 08.03.008

Bromley, R. (2006). On and Off Campus: Colleges and Universities as Local Stakeholders. Planning, Practice \& Research, 21(1), 1-24. https://doi.org/10.1080/02697450600901 400

Brown, T. J., Dacin, P. A., Pratt, M. G., \& Whetten, D. A. (2006). Identity, Intended Image, Construed Image and
Reputation: An Interdisciplinary Framework and Suggested Terminology. Journal of the Academy of Marketing Science, 34(2), 99-106.

Caruana, A. (2002). Service loyalty; The effects of service quality and the mediating role of customer satisfaction. European Journal of Marketing, 36(7/8), 811-828.

https://doi.org/10.1108/03090560210430 818

Eberl, M., \& Schwaiger, M. (2005). Corporate reputation: disentangling the effects on financial performance. European Journal of Marketing, 39(7/8), 838-854. https://doi.org/10.1108/03090560510601 798

Engwall, L. (2007). The anatomy of management education. Scandinavian Journal of Management, 23, 4-35. https://doi.org/10.1016/j.scaman.2006.12 .003

Etzkowitz, H., Webster, A., Gebhardt, C., Regina, B., \& Terra, C. (2000). The future of the university and the university of the future: evolution of ivory tower to entrepreneurial paradigm. Research Policy, 29, 313-330.

Fernandez, J. L. (2010). An Exploratory Study of Factors Influencing The Decision of Students to Study at Universiti Sains Malaysia. Kajian Malaysia, 28(2), 107136.

Finch, D. J., Hamilton, L. K., Baldwin, R., \& Zehner, M. (2013). An exploratory study of factors affecting undergraduate employability. Education + Training, 55(7), 681-704. https://doi.org/10.1108/ET-07-20120077

Fombrun, C., \& Shanley, M. (1990). What's in a Name? Reputation Building and Corporate Strategy. Academy of Management Journal, 33(2), 233-258.

Gaultier-Gaillard, S., \& Louisot, J.-P. (2006). Risk to Reputation : A Global Approach. The Geneva Papers on Risk and Insurance. Issues and Practice, 31(3), 
425-445.

https://doi.org/10.1057/palgrave.gpp.25

Giuliani, E., \& SPRU. (2010). Network Dynamics in Regional Clusters : A New Perpecstive from an Emerging Economy. Retrieved from http://isapapers.pitt.edu/

Gotsi, M., \& Wilson, A. M. (2001). Corporate reputation: seeking a definition. Corporate Communications An International Journal, 6(1), 24-30.

Gray, E. R., \& Balmer, J. M. T. (1998). Managing Corporate Image and Corporate Reputation. Long Range Planning, 31(5), 695-702.

Grunig, J. E. G. and L. A., Sriramesh, K., Huang, Y.-H., \& Lyra, A. (1995). Journal of Public Relations Models of Public Relations in an International Setting. Journal of Public Relations Research, 7(3), 163-186.

Harahap, D. A. (2015). Analisis Faktor-Faktor yang Mempengaruhi Keputusan Pembelian Konsumen di Pajak USU (Pajus) Medan. Jurnal Keuangan Dan Bisnis, 7(3), 227-242.

Harahap, N. (2004). Analisis Faktor-Faktor Yang Mempengaruhi Keputusan Mahasiswa Dalam Menempuh Pendidikan Pada Politeknik LP3I Medan. Universitas Sumatera Utara. Retrieved from e-USU Repository ح 2004 Universitas Sumatera Utara

Hatch, M. J., \& Schultz, M. (1997). Relations between organizational culture, identity and image, 31(5), 356-365.

Heath, R. L., \& Vasquez, G. (2001). Handbook of Public Relations. Thousand Oaks California: Sage Publications.

Helgesen, Ø. (2008). Marketing for Higher Education: A Relationship Marketing Approach. Journal of Marketing for Higher Education, 18(1), 50-78. https://doi.org/10.1080/08841240802100 188

Helm, S. (2007). One reputation or many? of corporate reputation. Corporate Communications An International Journal, $12 \quad$ (3), 238-254. https://doi.org/10.1108/13563280710776
842

Hilgers, M. G., Flachsbart, B. B., \& Elrod, C. C. (2012). Collaborative international education: reaching across borders. Multicultural Education \& Technology Journal, 6(1), 45-56. https://doi.org/10.1108/17504971211216 319

Indrajit, R. E., \& Djokopranoto, R. (2006). Manajemen Perguruan Tinggi Modern. Yogyakarta: Andi.

Ivy, J. (2008). A new higher education marketing mix: the 7Ps for MBA marketing. International Journal of Educational Management, 22(4), 288299.

https://doi.org/10.1108/09513540810875 635

Jarvinem, R., \& Suomi, K. (2011). Reputation attributes in retailing services: managerial perspective. Managing Service Quality, 21(4), 410-423. https://doi.org/10.1108/09604521111146 270

Jung, N. Y., \& Seock, Y. K. (2016). The impact of corporate reputation on brand attitude and purchase intention. Fashion and Textiles, 3(20), 1-15. https://doi.org/10.1186/s40691-0160072-y

Khoiriyah, D., Susilawati, M., \& Nilakusumawati, D. P. E. (2013). Faktor-Faktor Yang Mempengaruhi Minat Mahasiswa Asal Luar Bali Kuliah di FMIPA Universitas Udayana Bali. EJurnal Matematika, 2(1), 24-32.

Kornberger, M. (2010). Brand Society. New York: Cambridge University Press. Retrieved from www.cambridge.org

Kotler, P. (2002). Manajemen Pemasaran (Edisi Mile). Jakarta: Salemba Empat.

Kotler, P. (2005). Manajemen Pemasaran (I dan II). Jakarta: Indeks.

Mazzarol, T., \& Soutar, G. N. (2012). Revisiting the global market for higher education. Asia Pacific Journal of Marketing and Logistics, 24(5), 717737.

https://doi.org/10.1108/13555851211278 
079

Melewar, T. C., Karaosmanoglu, E., \& Peterson, D. (2005). Corporate identity: Concept, components and contribution. Journal of General Management, 31(1), 59-81.

https://doi.org/10.1177/03063070050310 0104

Morgeson, F. P., \& Nahrgang, J. D. (2008). Same as It Ever Was: Recognizing Stability in the BusinessWeek Rankings. Academy of Management Learning \& Education, 7(1), 26-41.

Petruzzellis, L., \& Romanazzi, S. (2010). Educational value: how students choose university. International Journal of Educational Management, 24(2), 139158.

Policano, A. J. (2007). The rankings game: and the winner is . . Journal of Management Development, 26(1), 4348.

https://doi.org/10.1108/02621710710720 077

Post, J., \& Griffin, J. (1997). Corporate reputation and external affairs management. Corporate Reputation Review, 1(1/2), 165-171.

Prodan, I., \& Drnovsek, M. (2010). Technovation Conceptualizing academic-entrepreneurial intentions : An empirical test. Technovation, 30(5-6), 332-347.

https://doi.org/10.1016/j.technovation.20 10.02.002

Ressler, J., \& Abratt, R. (2009). Assessing the impact of university reputation on stakeholder intentions. Journal of General Management, 35(1), 35-45.

Robbins, S. P. (2007). Perilaku Organisasi. Jakarta: PT. Indeks Kelompok Gramedia.

Schiffman, L. G., \& Kanuk, L. L. (2007). Perilaku Konsumen (Edisi Kedu). Jakarta: PT. Indeks Kelompok Gramedia.

Sojkin, B., Bartkowiak, P., \& Skuza, A. (2012). Determinants of higher education choices and student satisfaction: the case of Poland. Higher Education, 63, 565-581. https://doi.org/10.1007/s10734-0119459-2

Sontaite, M. dan Bakanauskas, A. (2011). Measurement Model of Corporate Reputation at Higher Education Institutions : Customers' Perspective. Systematic Research, 59, 115-130.

Sultan, P., \& Wong, H. Y. (2012). Service quality in a higher education context : an integrated model. Asia Pacific Journal of Marketing and Logistics, 24(5), 755784.

https://doi.org/10.1108/13555851211278 196

Swastha, B., \& Handoko, T. H. (2008). Manajemen Pemasaran, Analisa Perilaku Konsumen (Edisi Pert). Yogyakarta: BPFE.

Thursby, M., Thursby, J., \& Gupta-Mukherjee, S. (2005). Are There Real Effects of Licensing on Academis Research? A Life Cycle View. Retrieved from http://www.nber.org/papers/w11497

Vercic, A. T., \& Vercic, D. (2007). Reputation as Matching Identities and Images: Extending Davies and Chun's (2002) Research on Gaps between the Internal and External Perceptions of the Corporate Brand. Journal of Marketing Communications, 13(4), 277-290. https://doi.org/10.1080/13527260701300 151

Vidaver-cohen, D. (2007). Reputation Beyond the Rankings: Business School Research. Corporate Reputation Review, 10(4), 278-304. https://doi.org/10.1057/palgrave.crr.1550 055

Wedlin, L. (2006). Ranking Business Schools Forming Fields, Identities and Boundaries in International Management Education. USA: Edward Elgar Publishing Limited.

www.uisu.ac.id. (n.d.). Universitas Islam Sumatera Utara. Retrieved from http://uisu.ac.id/

$\{$ Bibliography\} 